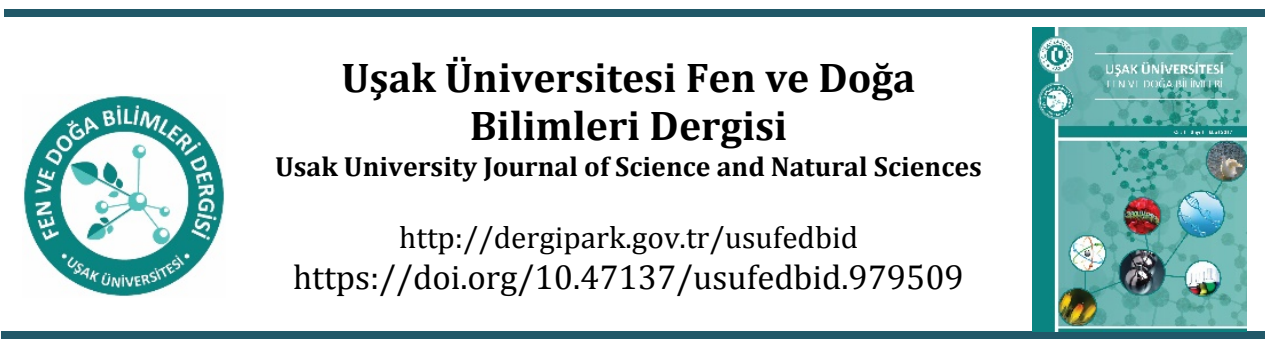

Derleme Makalesi

\title{
Nohut Üretiminde Sorun Olan Yabancı Otlar ve Kimyasal Mücadele Çalışmaları
}

\author{
Burhan DILLEK, Derya ÖĞ̈̈T YAVUZ*
}

*Bitki Koruma Bölümü, Ziraat Fakültesi, Ușak Üniversitesi, Ușak, Türkiye

\begin{abstract}
The rapid increase in the world's population not only causes destructions on natural resources and the environment but also raises problems in terms of access to food and food safety. Weeds are one of the factors that limit chickpea cultivation, which has an important place in adequate and quality nutrition, has wide adaptability, can be grown in many climates and is not selective in terms of soil demand, and result in yield losses. In this study, the studies on the weed species which cause problems in chickpea production and chemical control methods were reviewed. As a result of this compilation, it is understood that yield losses associated with weeds are also undeniable in the chickpea production areas, as in all cultivated plants in agricultural production, and the problem species should be identified in the early period and appropriate control/control techniques should be made at the appropriate time.
\end{abstract}

Keywords: Chickpea, weeds, herbicide.

\section{Özet}

Dünya nüfusundaki hızlı artış bir taraftan doğal kaynaklar ve çevre üzerinde tahribatlar oluștururken, diğer taraftan gıdaya ulaşma ve gıda güvenilirliği açısından sorunları gündeme getirmektedir. Yeterli ve kaliteli beslenmede önemli bir yeri olan, geniş adaptasyon yeteneğine sahip, birçok iklimde yetişebilme özelliği ile toprak isteği açısından seçici olmayan nohut yetiștiriciliğini sınırlandıran ve verim kayıplarına sebep olan faktörlerden biri de yabancı otlardır. Bu çalışmada nohut üretiminde sorun olan yabancı otların türleri ve kimyasal mücadele yöntemleri hakkında yapılan araștırmalar derlenmiștir. Bu bilgiler ıșığında, tarımsal üretimde tüm kültür bitkilerinde olduğu gibi nohut üretim alanlarında da yabancı otlardan kaynaklı verim kayıplarının yadsınamaz olduğu, sorun olan türlerin erken dönemde teşhislerinin ve uygun mücadele/mücadele tekniklerinin uygun zamanda yapılması gerekliliği anlaşılmaktadır.

Anahtar Kelimeler: Nohut, yabancı otlar, herbisit.

(C)2021 Usak University all rights reserved.

\footnotetext{
*Corresponding author:

E-mail: derya.ogutyavuz@usak.edu.tr (ORCID ID: 0000-0001-9248-410X)
}

(C)2021 Usak University all rights reserved. 


\section{Giriş}

Dünya nüfusundaki hızlı artış bir taraftan doğal kaynaklar ve çevre üzerinde tahribatlar oluștururken, diğer taraftan gıdaya ulașma ve gıda güvenilirliği açısından sorunları gündeme getirmektedir. Dünya genelinde tarımı çok eski yıllardan beri yapılmakta olan yemeklik tane baklagiller insan beslenmesinde bitkisel kaynaklı protein gereksiniminin karşılanması bakımından büyük öneme sahiptir. Yüksek oranda ham protein içeren tane baklagiller özellikle lizin, lösin, izolösin gibi temel aminoasitler ile A, B vitamini ve mineral maddeler bakımından oldukça zengin olup [1], özellikle gelişmekte olan ülkelerin protein gereksiniminin karşılanmasında büyük öneme sahiptir.

Baklagiller içerisinde değerli bir bitki olan nohut artan dünya nüfusu için besleyici bir gıda olma özelliğinin yanı sıra iklim değişikliği ile daha da önemli hale gelmektedir [2]. Ülkemizde tarımı yapılan yemeklik tane baklagiller içerisinde kuru fasulye ve mercimekten sonra en fazla yetiștiriciliği yapılan Cicer genusundan Cicer arietinum'dur. Kökeni Doğu-Batı doğrultusunda Himalayalar'dan Yunanistan'a, Kuzey-Güney doğrultusunda Kırım'dan Etiyopya'ya kadar olan bölgedir. Mercimekten sonra kuraklığa ve sıcaklığa en çok dayanan bitki olması, nohudun yarı-kurak ve kurak alanların en önemli bitkilerinden birisi yapmaktadır. Bu nedenle, ülkemizin Doğu, Güneydoğu ve Orta Anadolu bölgelerinin tarımsal deseninde kendine yer bulmuştur. Türkiye'de hemen hemen her coğrafik bölgede nohut yetiştirilebilse de Orta Kuzey Anadolu Bölgesi nohut tarımının en fazla yapıldığı bölgedir. Bu bölgeyi sırasıyla Akdeniz, Orta Güney Anadolu, Ege, Orta Doğu Anadolu ve diğer bölgeler izlemektedir [1]. Dünyada nohut üreten bașlıca ülkeler sırasıyla Hindistan, Avustralya, Burma, Türkiye, Rusya, Pakistan, Amerika Birleşik Devletleri, İran, Meksika, Tanzanya, Kanada, Arjantin, İspanya, Yemen, Suriye ve Etiyopya olmakla beraber, dördüncü sırada bulunan ancak son yıllarda üretimini büyük ölçüde artıran Türkiye 2017 yılında dünya üretiminin \% 3.67'sinden fazlasını oluşturmuştur [3].

Ortalama nohut verimi, üretici ülkeler arasında büyük farklılıklar göstermektedir. İran, Malavi, Fas, Pakistan ve Suriye gibi nispeten verim miktarı düşük ülkelerden Etiyopya ve Meksika gibi nispeten yüksek verimlere kadar uzanan bu farklılık, ortalama 500-600 kg ha-1 olarak karşımıza çıkmaktadır. En büyük üretici olan Hindistan'ın ortalama verim miktarı yaklaşı $900 \mathrm{~kg} / \mathrm{ha}$ olup, dünya üretiminde \% 64,7lik bir paya sahiptir. Meksika'nın sahip olduğu $2000 \mathrm{~kg}$ ha-1 gibi yüksek verimliliğin sebebinin ise büyük ölçüde bitkinin çoğunun serin kış mevsiminde sulanması ve yetiştirilmesinden kaynaklandığı düşünülmektedir [3].

Nohut üretimini sınırlandıran ve verim düşüklüğüne sebep olan birçok biyotik ve abiyotik faktörlerin varlığı bilinmekte olup bunlardan Antraknoz, Fusarium solgunluğu, Rhizoctonia ve Pythium kök çürüklüğü, nohutta görülebilen hastalıklar olarak karşımıza çıkmaktadır. Nohut üretiminde dünyada ve ülkemizde sıklıkla görülen hastalıkların başında fungal bir etmen olan Ascochyta rabiei (Pass.) Labr. (Nohut Antraknozu) gelmektedir [4]. Nohut yaprak sineği [Liriomyza cicerina (Rond.) (Diptera:Agromyzidae)] de nohudun ana zararlılarından olup, bunun yanında nohut yetiştiriciliğini sınırlandıran ve verim kayıplarına sebep olan diğer faktörlerden biri de yabancı otlardır [5].

Bu derlemede ülkemizde iç tüketim yanında ihracat bitkisi olan ve binlerce yıldan bu yana tarımı yapılan ender bitkilerden birisi olan nohut üretiminde sorun olan yabancı otlar, verim kayıpları ve kimyasal mücadele olanakları ele alınmıștır. 


\section{Yabancı Ot Mücadelesinin Önemi ve Verim Kaybı}

Erken gelişme dönemlerinde, yavaş gelișme oranı ve sınırlı yaprak alanı gelişimi nedeniyle yabancı otlara karșı rekabet gücü oldukça zayıf bir bitki olan nohut, [6] erken gelişme dönemindeki yavaşlığı ve kısa boy gibi özelliklerinden dolayı, yabancı ot rekabetinde oldukça hassastır ve yabancı ot mücadelesi uygun zamanda yapılmazsa, genellikle \% 75'e varan önemli verim kayıpları meydana gelebilmektedir [7]. Yabancı otlar ile kültür bitkileri arasında yer, ışık, su ve karbondioksit rekabeti bulunmakta ve bu nedenle nohutta yabancı ot yönetimi, bitki korumanın ve üretim potansiyelini geliştirmenin önemli bir bileşeni olarak görülmektedir. Yabancı otlardan kaynaklanan kayıplar, hasatta ekstra maliyete ve ürün kalitesinin düşmesine neden olmaktadır [8]. Bazı hastalık ve zararlı etmenlere de konukçuluk etmektedirler [9,10-11]. Yabancı otlar, topraktan bitki besin elementlerini ve suyu daha verimli bir şekilde kullanabilmekte ve çoğu yabancı ot türü daha hızlı büyümekte bu nedenle nohudun güneş ıșığını ve fotosentez aktivitesini etkileyerek bitki verimliliğini olumsuz yönde etkilemektedir [12].

Nohut, yabancı ot rekabeti özellikle erken dönemde meydana geldiğinde yeterli derecede rekabet yeteneğine sahip bir bitki değildir [13]. Yabancı otların, kışlık baklagil üretiminde tane veriminde \% 50 oranında azalmaya neden olduğu, bazı yıllarda ise verim almayı bile engellediği yapılan çalıșmalarla belirtilmiștir [14]. Nohutta yabancı otlardan kaynaklı verim kaybının \% 40-90 olduğu belirtilirken [15] Solh ve Pala [16] yapmış oldukları çalıșmada nohutta yabancı otlardan kaynaklanan verim kaybını \% 40-87 olarak belirtmișlerdir. Yabancı otların șiddetli istilasının nohudun yetiștirilme süresi boyunca tohum veriminde yaklașık \% 66.4 ve 48.3 azalmaya neden olduğunu belirtmișlerdir [17]. Farklı araștırmacılar tarafından farklı ülkelerde ve bölgelerde yürütülen çalışmalarda, Hindistan'da \% 40-94, Batı Asya'da \% 40-75, Kuzey Afrika'da \% 13-98 ve İtalya'da \% 35 oranında yabancı otların sebep olduğu verim kayıpları belirtilmiștir [18]. Barker [13] tarafından yabancı otların nohuttun erken gelişme döneminde \% 81 ile 97 gibi oldukça yüksek oranlarda verim kaybına sebep olduğu ifade edilmiştir.

\section{Nohut Üretiminde Sorun Olan Yabancı Ot Tür ve Yoğunluklarının Belirlenmesi Amacıyla Yürütülen Çalışmalar}

Nohut üretiminde karşılaşılan zorlukların başında yer alan yabancı otlarla etkili bir mücadele için öncelikle yabancı ot türlerinin belirlenmesi oldukça önemli olup, birçok türün erken gelişme döneminde tespit edilmesi zor olsa da mücadele açısından oldukça önemlidir. Belirli bir yerin yabancı ot florası hakkındaki bilgi, etkili bir yabancı ot yönetimi stratejisi için ilk ve en önemli adımlardan birisidir. Nohut üretim alanlarını istila eden yabancı ot türleri, ülkedeki iklim koşullarına bağlı olarak bölgeden bölgeye değişiklik gösterebilmektedir [19]. Floradaki yabancı otların ortaya konulması, yapılacak mücadele stratejileri ve uygulanacak yöntemlerin belirlenmesi açısından da önemlidir [20]. Dünyada ve ülkemizde farklı bölgelerde nohut üretim alanlarında survey çalışmaları yürütülmüş ve bölgenin ekolojik özelliklerine, topoğrafik yapısına, toprak yapısına, ekim sıklığına, ekim şekline, ekim nöbeti sistemine, sulama durumuna, tercih edilen çeşitlere bağlı olarak yabancı ot türlerinde ve yoğunluklarında farklılıkların gözlemlenebileceği birçok araştırmacı tarafından ortaya konulmuştur [21,22,23,24,25,26-27].

Son yıllarda ülkemizde ve dünyada nohut üretim alanlarında sorun olan yabancı ot türlerinin tespitine yönelik çalışmalar sunulmuştur.

Yemeklik tane baklagillerde yabancı ot sorunlarının değerlendirildiği survey çalışmaları sonucunda; Gaziantep'te Avena sterilis, Chrozophora tinctoria, Euphorbia spp., 
Kahramanmaraş'ta Sinapis arvensis, Scandix pecten-veneris, Chenopodium album; Mersin'de C. album, Chondrilla juncea, Galium aparine; Adana'da Convolvulus arvensis, $C$. juncea, Centaurea cyanus; Antalya'da Salvia syriaca, A. sterilis, Tragopogon spp. en yoğun görülen türler olarak ifade edilmiștir [28]. Diyarbakır ve yöresinde nohut tarlalarında sorun olușturan yabancı otlardan Cichorium intybus'un il genelinde $\mathrm{m}^{2}$ de 1 adetten fazla yoğunluk gösteren önemli bir tür olduğu ifade edilmiștir [29]. Karaman ve yöresinde nohut ekim alanlarında en yaygın türlerin sırasılla C. album, C. arvensis, Amaranthus retroflexus olduğu belirtilmiștir [30]. Tokat ve Zile yöresinde yapılan çalıșmada, Avena sterilis'in en yoğun tür olduğunu belirtilmiștir [31]. Kahramanmaraş ilinde yürütülen çalıșmada ise birim alandaki yoğunluğu bakımından C. album, A.retroflexus, S. arvensis, Cynodon dactylon, Elymus repens ilk sıralarda yer alan türler olmuștur [32]. Hindistan'ın iki farklı șehrinde yapılan çalıșmada; Raipur șehrinde yürütülen çalıșma alanında sirasiyla Medicago denticulata, Convolvulus arvensis, Chenopodium album, Melilotus indica ve Brachiaria mutica'nın baskın yabancı ot türlerinden bazıları olduğu tespit edilmiștir [33]. Monokotiller arasında Brachiria mutica, Echinochloa crus-galli, Cynodon dactylon ve Cyperus rotundus ile dikotiledonlardan Amaranthus viridis, Digera arvensis, Physalis minima, Euphorbia hirta, Parthenium hysterophorus ve Alternanthera sessilis'in Maharashtra şehrinde öne çlkan yabancı ot türlerinden olduğu belirtilmiştir [34]. Hindistan'ın Kanpur șehrinde yapılan bașka bir çalıșmada ise Chenopodium album Parthenium hysterophorus, Cynodon dactylon, Asphodelus tenuifolius, Fumaria parviflora, Anagallis arvensis, Cronopus didymus ve Spergula arvensis çalışma alanında hakim olan türler olurken [35] Jodhpur şehrinde yürütülen çalışmada ise Chenopodium murale, Chenopodium album ve Rumex dentatus istilası gözlemlenmiş, bunlar arasında Chenopodium murale'nin en baskın yabancı ot türü olduğu belirtilmiştir [36]. Etiyopya, Haramaya'da yapılan çalışmada Solanum nigrum, Medicago polymorpha, Galinsoga parviflora, Commelina benghalensis, Parthenium hysterophorus ve Cyperus rotundus'un önemli türlerden olduğu ifade edilmiştir [37].

Ülkemizde farklı illerde ve bölgelerde nohut üretim alanlarında yapılan yabancı ot tür ve yoğunlukları ile ilgili çalıșmalar incelendiğinde; çalıșmaların oldukça sınırlı sayıda olduğu görülmüș ve survey sonuçlarına göre öne çlkan türler Avena sterilis, Amaranthus retroflexus, Chenopodium album, Chondrilla juncea, Convolvulus arvensis, Cichorium intybus, Cynodon dactylon, Elymus repens, Galium aparine ve Sinapis arvensis olarak kaydedilmiştir.

Verim ve kaliteyi etkileyen yabancı ot türlerinin ve yoğunluklarının belirlenmesi, bölge için önemli türlerin ve ileri süreçte risk olușturabilecek türlerin ortaya konulması açısından oldukça önemli bir adımdır. Ayrıca yabancı otun mücadelesine yönelik çalıșmaların geliștirilmesi açısından da tür ve yoğunlukların belirlenmesi önem taşımaktadır. Söz konusu türlerin yaygınlığına bağlı olarak etkili kontrol yöntemleri erken dönemde uygulanmadığı ve kültürel faaliyetlere dikkat edilmediği takdirde gelecek dönemlerde yabancı ot sorunu artarak önemli verim kayıplarının yaşanmasına zemin olușturabilecektir. Solh ve Pala [16] yabancı ot kontrolünde toprak ișleme, ekim yöntemleri ve ekim zamanlarının etkili olduğunu, yabancı ot mücadelesinin yapılmadığı kıșlık nohut ekiminde $1250 \mathrm{~kg} \mathrm{ha}^{-1}$ olan verimin, yabancı ot kontrolü yapıldı̆̆ında 1500 $\mathrm{kg} \mathrm{ha}^{-1}$ a kadar çıtı ğını belirtmișlerdir. Ayrıca yabancı ot kontrolünün yapıldığı yazlık ekimde ise verimin $1150 \mathrm{~kg} \mathrm{ha}^{-1}$ dan $1250 \mathrm{~kg} \mathrm{ha}^{-1}$ a kadar yükseldiği ifade edilmiștir. Bhalla ve ark. [38] çalıșmalarında nohutta herbisit uygulamasının \% 50-54 oranında yabancı ot kontrolü sağladığını ifade etmișlerdir. Nohut üretiminde çıkıș öncesi herbisitlerin \% 12-14 ve çıkıș sonrası herbisitlerin \% 6-23'lük verim artıșı sağladığı belirtilmiștir [39]. Etkili bir yabancı ot kontrolü ile nohut veriminin \% 17-105 arasında artışının olabileceği ifade edilmiștir [18]. 


\section{Nohut Üretiminde Yabancı Otların Kontrolünde Kimyasal Mücadele Çalışmaları}

İnsan sağlığının, çevrenin ve biyolojik çeşitliliğin korunmasının ön plana çıktığı günümüzde zirai mücadelenin agro-ekosistem ve sürdürülebilir tarımsal üretim dikkate alınarak yapılması bir zorunluluk haline gelmiştir. Yabancı otların zararını en aza indirmek amacıyla çeşitli mücadele yöntemleri uygulanmaktadır. Birçok kültür bitkisinde olduğu gibi nohut üretiminde de yabancl ot kontrol metotları; kültürel mücadele, mekanik mücadele, kimyasal mücadele olarak sıralanabilir. Yabancı otların nohutta zararlarının en aza indirilmesinde ürün rotasyonu, iyi bir tohum yatağı hazırlığı, ekim derinliği, ekim öncesi yüzlek sürüm yapmak gibi bazı kültürel önlemlerin alınması gerekmektedir. Yapılan çalıșmalarda yabancı otların baklagil bitkilerinde verimi önemli ölçüde etkilediği, verim azalmalarına neden olduğu bildirilmektedir. Bu nedenle verimi arttırabilmek amacıyla en az bir kere yabancı ot mücadelesi yapılması zorunluluğu bulunmaktadır. Ancak ülkemizde nohudun sıraya ekimi yaygın olmaması nedeniyle bu işlem genellikle el çapası ya da el ile yolma șeklinde yapılmaktadır. Ürünün maddi getirisinin mücadele masrafları için yetersiz olması nedeniyle birçok üretici nohudun ekim işlemini tamamladıktan sonra nohudu kendi gelişimine bırakmaktadırlar.

Nohut, erken gelişme döneminde yavaş gelişme oranı nedeniyle hem sulu hem de kurak alanlarda yabancı otlar tarafından ciddi şekilde istila edilebilmektedir. Bu nedenle yabancı otların yeni alanlara girmesini, yerleşmesini ve yayılmasını en aza indirmek için yapılacak kültürel mücadele yöntemleri, verim açısından oldukça önemli olup, ekim zamanı da yabancı ot-kültür bitkisi arasındaki rekabet yeteneklerini önemli ölçüde etkilemektedir. Erken gelișme döneminde yabancı ot rekabetinden korumak ve yabancı ot popülasyonunun azaltılması amaçlanmaktadır Kullanılan hasat ve toprak işleme aletlerinin temizliği, yabancı otların tohum bağlamadan alandan uzaklaştırılmaları, sertifikalı tohumluk kullanımı gibi faaliyetlerle yabancı otların yoğunluğu önemli ölçüde azaltılabilmektedir. Nohut ekiminden 15-20 gün önce yapılan yüzlek toprak işlemenin çimlenen kışlık tek yıllık yabancı otları yok etmek hem de yazlık yabancı ot tohumlarının çimlenmesini teşvik ederek oluşan yabancı ot fidelerinin ekim işlemi ile ortadan kaldırılmasına hizmet etmektedir [40]. Ayrıca iyi bir toprak hazırlığı ile hem toprakta yeteri kadar nem birikmekte hem de yabancı ot yoğunluğunda önemli ölçüde azalmalar kaydedilmektedir. Ayrıca dekara kullanılan uygun tohum miktarı ve sıra arası mesafe gibi tarımsal uygulamaların da yabancı otları etkili bir şekilde baskılayabilmesine katkı sağlamaktadır. Malik ve ark. [41] yaptıkları çalıșmada nohut ekim tarihinin 20 Kasım'dan 5 Aralık'a kadar gecikmesiyle Chenopodium album yoğunluğunun azaldığını, Lathyrus aphaca'nın ise arttığını gözlemlemișlerdir. Blessdal [42] kullanılan tohum oranı ve sıra arasındaki değișiklikler sayesinde artan bitki yoğunluğunun, yabancl otların yoğunluğunu etkili bir șekilde bastırdığını ve gelișimini azalttığını bildirmiștir. Whish ve ark. [43] Avustralya'nın New South Wales eyaletinde yaptıkları çalışmada, sıra arası 32 cm ekilen bitkilerden elde edilen nohut veriminin, otsuz koşullarda ve geniş sıra $(64 \mathrm{~cm})$ aralıklı ekimlerden elde edilen verimden daha yüksek olduğu belirtilmiștir. Numan ve ark. [44] nohutta yabancı ot mücadelesinde en ekonomik ve faydalı yöntemin iki kez elle yolma olduğunu, bitki için maksimum besin mevcudiyeti nedeniyle artan verim ve verim bileșenlerinin, toprağı (köklerin nüfuz etmesi için) gözenekli hale getirdiği ve toprağın su tutma kapasitesini arttırdığını belirtmiş̧lerdir.

Yabancı ot rekabetine karşı oldukça hassas olan nohut yetiştiriciliğinde yabancı otlar uygun zamanda kontrol edilmezse, çoğu zaman önemli kayıplar meydana gelmektedir. $\mathrm{Bu}$ kayıpların önlenmesinde en etkili yabancı ot kontrol yöntemlerinden biri herbisitlerdir. Herbisitler, 20. yüzyılın en etkili yabancı ot mücadele aracı olarak kullanılmakta olup 
yabancı ot yoğunluğunu ve toprakta tohum bankası rezervini azaltmada herbisitlerin önemli etkileri bulunmaktadır [45].

Tohum kaynaklarının yenilenmesini sınırlayan yabancı ot yönetim programlarının tasarlanması oldukça önemli olup, ekim nöbeti, herbisitler ve toprak işleme gibi uygulamalar topraktaki tohumların sayısının ve çeşitliliğinin sınırlandırılmasında önemli rol oynamaktadır. Yabancı ot tohum yoğunluğunun düşürülmesinden sonra yeterli miktarda herbisitin uygun zamanda, uygun dozda kullanılmasıyla bu yoğunluk düşük tutulabilmektedir.

Nohut yetiştiriciliğinde sorun olan yabancı ot türlerinin mücadelesinde hem işçilik maliyeti hem de işçi bulmakta yaşanılan sıkıntılardan dolayı elle yolma, çapalama işlemi zor bir hal almış durumdadır. Elle yabancı ot mücadelesi geniş alanlarda uygulanması hem zor hem de zaman alıcı pahalı bir yöntemdir [46]. Bu nedenle etkili yabancı ot yönetimi genellikle kimyasal mücadele ile sağlanmakta ve yapılan çalışmalarda nohutta kimyasal mücadele yöntemleri ile yabancı otların yaklaşık \% 80-83 oranında kontrol altına alındığı ve \% 50 tane verimi artışı sağlandığı belirtilmektedir. Tarımsal uygulamaların en önemli ve vazgeçilmezlerinden birisi olan herbisit uygulamaları günümüzde; etkisini kısa sürede göstermesi, etki süresinin uzun olması, uygulama kolaylığı ve üretim maliyetlerini düşürmesinden dolayı yabancı otlarla mücadelede dünyada en yaygın kullanılan ve üretim artışında da önemli rolü olan kontrol yöntemidir. Söz konusu özelliklerinden dolayı herbisitler, üreticiler için vazgeçilmez bir yöntem olup herbisitlerin günümüzde kullanımı gün geçtikçe de artış göstermektedir [47, 48-49]. Tohum bağlama döneminde yavaş gelişimi, yabancı otlar ile mücadelede önemli olan gölgelemenin seyrek oluşu, çoğu zaman yabancı otlara karşı kimyasal mücadeleyi zorunlu kılmaktadır [50].

Entegre yabancı ot yönetimi uygulamalarından biri olan herbisitler nohudun çıkışından 20 ve 40 gün sonra çapalama ile entegre halinde uygulanabilmektedir [51]. Bitkinin çimlenme dönemi, yabancı ot mücadelesinde herbisitin uygulanacağı ve etkili olacağı uygun zaman olarak görülmektedir.

Nohut yetiştiriciliğinde yabancı otların kimyasal mücadelesinde farklı ülkelerde farklı etkili maddeler ruhsatlı olup, ülkemizde; çıkış öncesi flurochloridone, isoxaflutole, linuron, metolachlor+terbuthylazine, pendimethalin; çıkış sonrası ise aclonifen, quizalafop-p-ethyl, pyridate etkili maddeler kullanılmaktadır [40]. Toprağa uygulanan herbisitlerin avantajı, kültür bitkisi ile yakın zamanda çimlenen yabancı otların sayısını azaltmaları ve canlılığı devam eden yabancı otların çıkış sonrası herbisit uygulamalarına karşı duyarlı hale getirmeleridir. Toprağa uygulanan herbisitler ekimden önce uygulanmıșsa genellikle toprağa karıștırılmakta ve bu sayede herbisitlerin çevre koşullarından etkilenmesi önlenerek etkinliğinin optimum olması amaçlanmaktadır [52]. Ekimden sonra toprak herbisitleri kullanıldığında, kültür bitkisi çıkışından önce toprak yüzeyine uygulanmaktadır. Çıkış öncesi kullanılan herbisitler, tarımsal üretimde önemli bir yere sahip olup yabancı ot yoğunluğunu azaltarak çıkış sonrası uygulamaları tamamlamakta ve çıkış sonrası uygulamaların seçimi ve zamanlaması için avantaj sağlamaktadırlar [53]. Çıkış öncesi herbisitleri seçerken çok sayıda faktör dikkate alınmaktadır. Uygulama ile kontrol edilecek olan yabancı ot yoğunluğu oldukça önemlidir. Toprak tipi, nemi ve toprak organik madde miktarı önemli faktörler olup kullanılabilecek herbisitlerin dozlarını belirlemede etkin rol oynarlar [54]. Toprağın iyi işlenip keseksiz olmasına ve herbisitlerin homojen dağılımına özen gösterilmesi gerekmektedir. Çıkış öncesi herbisit uygulamalarının etkinliğinde, uygulamadan sonra toprak nemi önemli olup, nem olmadan bu tür herbisitlerin etkinliği de düşmektedir. 
Çıkış sonrası herbisitler ise kültür bitkisi ve yabancı ot tohumları çimlenip toprak yüzeyine çıktıktan sonra kullanılmaktadır [55].

Dünyada nohut üretiminde sorun olan yabancı otların mücadelesinde herbisitler, herbisit kombinasyonları ve mekanik mücadelenin değerlendirildiği çok sayıda çalışma mevcut olup, ülkemizde ise konu ile ilgili sınırlı sayıda olan benzer çalışmalardan elde edilen sonuçlar kronolojik olarak sunulmuştur.

Balyan ve ark. [56] tek başına 1.0 ve $1.5 \mathrm{~kg} \mathrm{ha}^{-1}$ dozlarda sırasıyla fluchloralin ve pendimethalin uygulanmasının, fluchloralin+pendimethalin ve fluchloralin+metribuzin kombinasyonundan nohut bitkisinin gelişimini ve verimini olumlu yönde etkilediğini tespit etmişlerdir. Yapılan çalışma sonuçlarında özellikle metribuzin uygulamasının, yabancı ot kontrolüne kıyasla önemli derecede daha iyi bitki gelişimi ve nohut verimi artışı sağladığı belirtilmiştir.

Samsun ekolojik şartlarında, kışlık nohut ekiminde yabancı otlarla mücadelede en uygun yöntemin belirlenmesi amacıyla farklı kültürel ve kimyasal yabancı ot mücadele metotlarının değerlendirildiği çalışmada; yabancı otların kültürel mücadelesinde devamlı ve iki kez yabancı ot kontrolü yapılmıștır. Kimyasal mücadelesinde ise bazı herbisit ve herbisit kombinasyonları ele alınmıștır. Devamlı yabancı ot kontrolü ile en etkili yabancı ot kontrolü ve en yüksek tane verimi sağlanmıştır. Ancak bu uygulamanın iş gücü ve zaman bakımından ekonomik olmadığl, çıkış öncesi Igran+Kerb $\left(300+50 \mathrm{gr} \mathrm{da}^{-1}\right)$ ve Maloran+Kerb (250+50 $\left.\mathrm{gr} \mathrm{da}^{-1}\right)$ herbisit karıșımlarının tavsiye edilebileceği belirtilmiştir. Yabancı otlardan kaynaklı tane verim kayıplarının ise \% 20.97-72.08 arasında değișiklik gösterdiği bildirilmiştir [57].

Nohutta yabancı otların kontrolünde çıkış öncesi yedi, çıkış sonrası on uygulama ile el çapası, elle yolma ve yabancı otlu bırakılarak yürütülen çalışmada; dar yapraklı yabancı otlara karşı, clethodim ve haloxyfop ile geniş yapraklı yabancı otların kontrolünde bentazone, cyanazine, MCPB, metribuzin, ve terbuthylazine etkinliği ele alınmıștır. Çalışma sonucunda en iyi yabancı ot kontrolü ve nohut bitkisinde en yüksek kuru madde oranının, çıkış öncesi cyanazine, terbuthylazine, cyanazine ile metribuzin kombinasyonu ve elle yolma işleminden elde edildiği belirtilmiştir [58].

Hindistan'ın Andhra Pradesh eyaletinde yapılan bir çalışmada, fluchloralin'in çıkış öncesi alachlor ve isoproturon uygulamalarından daha etkili olduğunu ortaya koymuşlardır. Nohutta herbisit kullanılmasıyla yabancı otların çoğunlukla kontrol altına alınabildiği ve tane veriminde artış sağlandığı bildirilmiştir [59].

Tahran'da nohutta yabancl ot mücadelesinde bazı herbisitlerin (chlorbromuron, methabenzthiazuron, terbutryn, cyanazine, propyzamide) performansının değerlendirildiği çalışmada; kimyasal yöntemlerin tane verimini arttırdığı, ancak elle yolma işlemiyle en yüksek verim artışının sağlandığı ifade edilmiştir [60].

Ege Bölgesi'nde iki farklı ekolojik alanda (Bornova ve Tavas) nohut ekim alanlarında yabancı otların kontrolü amacıyla; ekim öncesi (trifluralin), çıkış öncesi (imazethapyr, terbutryn, linuron) ve çıkış sonrası (linuron) uygulaması ile nohudun çıkışından 40 ve 70 gün sonra el çapası uygulamaları ile nohut bitkisinin kapsül bağlama döneminde elle yolma yöntemlerinin etkileri ele alınmıştır. Trifluralin, terbutryn ve el çapası uygulamalarında \% 90 ve üzeri etki elde edilmiştir. Sonuçta uygun toprak ve yağış koşullarında çapalama, ekim öncesi (trifluralin) ve çıkış öncesi (imazethapyr, terbutryn, linuron) uygulamaların verim artışı sağladığı, kurak geçen yıllarda herbisitlerin 
etkinliğinin azaldığı ve çıkış sonrası uygulanan linuron'un nohutta her iki lokasyonda da \% 80-85 oranında fitotoksik etkiye neden olduğu belirtilmiștir [61].

İtalya'da iki farklı şehirde (Gallina, Caltagirone) killi ve kumlu topraklarda Sultano nohut çeşidinde çıkış öncesi (imazethapyr+pendimethalin), (imazafos+pendimethalin) ve (pendimethalin) uygulamaları ve çiçeklenme döneminde elle yolma işleminin seçiciliği ve etkinliğinin değerlendirildiği çalışma sonucunda; killi topraklarda yapılan uygulamaların fitotoksik etkisinin olmadığı, ancak kumlu toprak koşullarında bitki gelişimi ve ürün veriminde azalmalar kaydedildiği, fitotoksik etkiler gözlemlendiği belirtilmiştir. Killi toprak koşullarında çıkış öncesi herbisit uygulamalarıyla önemli derecede verim artışının sağlanabileceği ifade edilirken, en düșük verimin hektara 3 litre imazafos+pendimethalin uygulamasından elde edildiği bildirilmiştir [62].

Nohutta tane verimi ve bin tane ağırlığı üzerine yabancl ot kontrol yöntemlerinden, mekanik yöntemler, çıkış öncesi (chlorbromuron tek başına veya mekanik yöntemlerle kombinasyon halinde) herbisit uygulamaları ile farklı etkili madde karıșımlarının (terbutryn+terbuthylazine+clomazone) etkinliği değerlendirilmiştir. Elde edilen sonuçlara göre, tek başına chlorbromuron uygulaması yetiştirme sezonu süresince fitotoksiteye neden olmadan geniş yapraklı yabancı otların kontrolünde en iyi sonucu (\%98) sergilemiştir. Terbutryne+terbutylazine+clomazone karışımlarının uygulandığı bitkilerde birkaç gün içerisinde kaybolan orta dereceli fitotoksik etkiler gözlemlenmiştir. Yapılan uygulamaların verime ve bin tane ağırlığına olan etkileri arasında istatistiki olarak farklar görülmemiş olsa da en yüksek verim oranının mekanik uygulamaların yapıldığı bitkilerden elde edildiği ortaya konulurken, chlorbromuron tek başına uygulanması ve mekanik mücadele yöntemlerinin tane veriminde $87-108 \mathrm{~kg} \mathrm{da}^{-1}$ oranında artışa sebep olduğu belirtilmiştir. Herbisit karışımlarında ise düşük oranda fitotoksite gözlenmiş olup tane veriminin $99 \mathrm{~kg} \mathrm{da}^{-1}$ olarak kaydedildiği ifade edilmiștir [63].

Hindistan'da nohutta yabancı ot kontrolünde, çıkış öncesi farklı herbisitler uygulanmış ve elde edilen sonuçlara göre hektara 1-1.5 kg pendimethalin uygulaması ve ekimden 30 gün sonra yapılan elle yabancı ot kontrolünde en yüksek (\% 85.5) oranda yabancı ot kontrolü sağlanmıștır. Pendimethalin uygulanan parsellere oranla kontrol parsellerinde ilk yıl \% 44, ikinci yıl \% 41 oranında verimin azaldığı ve pendimethalin'in metolachlor'dan daha etkili olduğu bildirilmiștir [64].

Kantar ve ark. [65] Erzurum kuru şartlarında, nohudun (cv. Aziziye-94) tohum ve toplam ürün verimi üzerine otlu kontrol ve elle yolma işlemi ile dokuz herbisitin (linuron, methabenzthiazuron, terbutryne, imazethapyr, fluazifop-p-butyl terbutryne+propyzamide, methabenzthiazuron+propyzamide, linuron+propyzamide, terbutryne+fluazifop-p-butyl) etkileri ele alınmıştır. Terbutryne+fluazifop-p-butyl, imazethapyr, linuron+propyzamide uygulamaları her iki yılda etkili bulunurken, methabenzthiazuron yağışlı geçen dönemde yeterli, ancak kurak geçen yılda ise zayıf etki göstermiştir. Terbutryne+fluazifop-p-butyl uygulamasının en etkili herbisit olduğu ifade edilmiștir. Kullanılan bu herbisitler ile Cirsium arvense, Chenopodium album, Amaranthus retroflexus ve Equisetum arvense'nin etkin bir şekilde kontrolü sağlanmıștır. Sonuç olarak, etkili herbisitlerin Erzurum şartlarında nohutta kullanılması ile otlu kontrole göre ürün artışı sağlanabileceği, bununla birlikte bir kez elle yabancı ot alımıyla da yabancı otların kontrol altına alınabileceği kanısına varıldığı belirtilmiştir.

Hindistan'da nohut üretiminde yabancı otların kontrolünde elle yolma ve herbisitlerin (linuron, pendimethalin, isoproturon) etkinliğinin ele alındığı çalışma sonucunda; yabancı ot kontrolü yapılmayan parsellerde verimin \% 54-56 oranında azaldığı ve $69 \mathrm{~kg}$ 
$\mathrm{da}^{-1}$ verim elde edildiği, en yüksek tane verimi $\left(159 \mathrm{~kg} \mathrm{da}^{-1}\right)$ ve yabancı ot kontrolünün ise (\% 93.3) linuron uygulaması ile sağlandığı belirtilmiștir. Ayrıca pendimethalin ve isoproturon uygulamalarının, elle yapılan yabancı ot kontrolü kadar etkili olduğu ve tane verimini artırdığı ifade edilmiştir [66].

Malik ve ark. [67] çıkış sonrası fluazifop butyl'in 0,75 kg ha-1'uygulamasının yabancı otları kontrol etmede etkili olduğunu belirtmişlerdir. Singh ve ark. [19] çıkış öncesi veya sonrası pendimethalin ve isoproturon uygulamasının ve çıkış öncesi pendimethalin'nin ekimden 45 gün sonra çapalama ile uygulanmasının nohut üretiminde yabancı ot kontrolünde etkili olduğunu belirtmişlerdir.

İki farklı lokasyonda (Ceylanpınar, Diyarbakır) ILC 482 nohut çeşidinde yabancı otlarla en uygun mücadele yönteminin belirlenmesi amacıyla; trifluralin, imazethapyr (çıkış öncesi ve çıkış sonrası), linuron, terbutryn, cyanazin ve çapa uygulaması otlu kontrol ile karşılaştırılarak verim, verim unsurları ve nodülasyon üzerine etkileri incelenmiştir. Ceylanpınar'da Amaranthus albus, Polygonum bellardii, Lactuca serriola, Vicia cracca ve Hordeum spp., Diyarbakır'da ise Anagallis arvensis ve Cichorium intybus baskın yabancı ot türleri olarak kaydedilmiş ve çalışma sonucunda, nohutta en etkili yabancı ot mücadele yönteminin, çapa uygulaması olduğu belirtilmiştir. Ceylanpınar'da terbutryn ve linuron; Diyarbakır'da ise imazethapyr (çıkış öncesi) ve linuron uygulamalarının yabancı ot kontrolü ve verim açısından diğer herbisitlere göre daha iyi sonuç verdiği ifade edilmiştir [68].

Lyon ve Wilson [69] tarafından Sidney'de yapılan çalışmada, ekim öncesi ethalfluralin $0.84 \mathrm{~kg} \mathrm{ha}^{-1}$ nin ve çıkış öncesi pendimethalin $1.12 \mathrm{~kg} \mathrm{ha}^{-1}$ nin birbirinden önemli ölçüde farklı sonuçlar vermediği de belirtilmiştir.

Orta Anadolu koşullarında nohutta yabancı ot kontrolü amacıyla farklı toprak işleme yöntemleri ve fosforlu gübrelerin verim ve verim öğelerine etkilerinin değerlendirildiği çalışmada; 2 farklı toprak işleme (pullukla, rototiller), 3 yabancı ot kontrol yöntemi (otlu, elle kontrol ve herbisit) ve 3 fosfor dozu (30, 60 ve $90 \mathrm{~kg}$ ) ele alınmıştır. Rototiller ile toprak işlemenin hem maliyeti düşürmesi hem de tahıl ve baklagil ekim nöbetinde toprakta canlı kök kanallarının bozulmadan kalmasını sağlaması açısından önemli olduğu vurgulanmıştır. Elle yolmanın mümkün olmadığı geniş alanlarda, herbisitlerin yabancı ot kontrolünde iyi bir çözüm sağlayabileceği, fosforlu gübre uygulamasının da nohutta verim artışına neden olabileceği belirtilmiștir [70].

Karaman ili nohut üretim alanlarında sorun olan yabancı otlar ve mücadele zamanının belirlenmesi amacıyla yürütülen çalıșmada; Chenopodium album, Convolvulus arvensis ve Amaranthus retroflexus türlerinin yoğun olduğu belirtilmiștir. Yabancı otlarla mücadelede kritik periyodun, nohudun çıkıșından itibaren 8. ve 9. haftalara kadar olduğu ve bu süreler dışında yapılan mücadelenin verim artışı açısından önemli bir etkisinin olmayacağı ortaya konulmuștur. Yabancı otlardan kaynaklı nohuttaki ürün kaybının ise $\% 29.09$ olduğu belirtilmiștir [31].

Nohut üretiminde verim ve kalite unsurlarını olumsuz yönde etkileyen problemlerden biri olan yabancl otların kontrolünde bazı herbisitler ve kombinasyonlarının değerlendirildiği çalıșmada; çıkış öncesi pendimethalin $1 \mathrm{~kg} \mathrm{ha}^{-1}$ uygulamasını takibinde çıkış sonrası imazethapyr $50 \mathrm{~g} \mathrm{ha}^{-1}$ ekimden 20 ve 40 gün sonra elle yolma uygulamalarıyla en yüksek yabancı ot kontrolü sağlanmıștır. Pendimethalin $0.5 \mathrm{~kg} \mathrm{ha}^{-1}$ ekimden 45 gün sonra elle yolma ile kombinasyonu yaklaşık $88 \mathrm{~kg} \mathrm{ha}^{-1}$ civarında kuru madde birikimi sağlamıș, ekim öncesi trifluralin $0.5 \mathrm{~kg} \mathrm{ha}^{-1}$ ile ekimden 45 gün sonra yapılan elle yolma kombinasyonu ise, $114 \mathrm{~kg} \mathrm{ha}^{-1} \mathrm{kuru}$ madde birikimine neden olmuștur. 
$\mathrm{Bu}$ nedenle, entegre uygulamaların, tek bașına herbisit uygulamalarından daha iyi performans gösterdiği bu nedenle de entegre yöntemlerin herbisitlerin tek bașına uygulanmasından önemli ölçüde üstün olabileceği ifade edilmiştir [71].

Isparta koşullarında nohutta yabancı ot mücadelesinde İspanyol nohut çeşidinde yabancı otlara karşı trifluralin (ekim öncesi), linuron (çıkış öncesi ve sonrası) ve bunların bir, iki ve üç defa çapalama ile kombinasyonun değerlendirildiği çalışma sonucunda; ekim öncesi trifluralin'nin nohutta önemli derecede fitotoksik etki yaptığı, çıkış sonrası linuron uygulamasının da bitkide az da olsa fitotoksik etkiye neden olduğu fakat nohut bitkisinin bunu zamanla tolere ettiği belirtilmiştir. Ekim+çıkış öncesi linuron+3 çapa uygulaması ile yüksek verim (115.3 $\mathrm{kg} \mathrm{da}^{-1}$ ) elde edilirken, en düşük verim $24.4 \mathrm{~kg} \mathrm{da}^{-1}$ ile trifluralin+ekim+çıkış öncesi linuron uygulamasında görülmüştür. Ekim+çıkış öncesi linuron+1 çapa uygulaması ise en iyi mücadelenin olduğu uygulama olarak ifade edilmiștir [72].

Nohutta sonbahar ve ilkbahar döneminde sulfentrazone uygulamasının yabancı otlar üzerine olan etkisinin değerlendirildiği bir çalıșmada; bahar döneminde yapılan sulfentrazone ile Sinapis arvensis kontrolünde en yüksek etkinin ve kontrolün sağlandığı belirtilmiştir [73].

Isparta koşullarında Gökçe nohut çeşidinde yabancı otlarla en uygun mücadele yönteminin belirlenmesi amacıyla; linuron-50 (çıkış öncesi), imazethapry (çıkıș öncesi) ve aclonifen (çıkış sonrası) etkili maddeleri ile çapa uygulamasının (çıkıştan sonra 12, 24, 36,48 ve 60. günlerde) verim ve verim unsurları üzerine etkilerinin değerlendirildiği çalışma sonunda; en etkili yabancı ot mücadele yönteminin, çıkıştan sonra 36. günde yapılan çapa uygulamasının olduğu ifade edilmiştir. Yabancı ot kontrolü ve verim değerleri bakımından imazethapry diğer herbisitlere göre daha iyi etki göstermiștir. Yabancı ot mücadelesinin yapıldığı uygulamalarda mücadele yapılmayan kontrol parsellerine göre \% 105 ile 142'ye varan verim artışının kaydedildiği belirtilmiştir [18].

Nohutta yabancı ot mücadelesinde kritik periyodun belirlenmesi amacıyla yürütülen çalışma; kritik periyodun başlangıcı ve sonu, üreticiler için \% 5 seviyesinde kabul edilebilir verim kaybına göre, lojistik ve 'Gompertz' modeller kullanılarak belirlenmiştir. $\mathrm{Bu}$ modellemede mücadele zamanı, nohudun yetişme sürecinde toplam sıcaklık isteği esas alınarak, yabancı otlu ve otsuz parsellerden elde edilen eğrilerin karşılaştırılması ile belirlenmeye çalışılmıştır. Çalışmada \% 5 seviyesinde kabul edilebilir verim kaybına göre kritik periyot, birinci yıl için çıkıştan sonra 2.32 inci hafta ile hasat arası, ikinci yıl için çıkış ile hasat arası ve üçüncü yıl için 0.34 üncü hafta ile hasat arası dönemler olarak tespit edilmiştir. Sonuç olarak, yabancl ot mücadelesinin nohut üretiminde oldukça önemli bir rolü olduğu belirtilmiștir [74].

Nohutta farklı ekim ve yabancı ot kontrol yöntemlerinin verim ve verim ögeleri üzerine etkilerinin belirlenmesi konulu çalışmada 2 farklı ekim yöntemi (serpme ekim, sıraya ekim), beş yabancı ot kontrol yöntemi (otlu, elle kontrol, imazethapyr, linuron, prometryne) ele alınmıștır. Elde edilen sonuçlara göre nohudun rekabete girmeden gelişimini normal bir şekilde sürdürmesi ve bakım işlerinin kolay yapılabilmesi açısından sıraya ekim, yabancı ot kontrol yöntemleri açısından ise elle kontrol uygulanmasının tercih edilmesi önerilmiştir. Ancak elle kontrolün mümkün olmadığı geniş alanlarda herbisitin iyi bir çözüm sağlayabileceği belirtilirken, imazethapyr'in verim ögeleri açısından daha iyi sonuçlar verdiği ifade edilmiştir [75].

Khope ve ark. [76] yaptıkları çalıșmalarında ekimden 30 gün sonra quizalofop $50 \mathrm{~g} \mathrm{ha}^{-1}$ uygulaması ile daha yüksek nohut verimi kaydetmişlerdir. Quizalofop'un ekimden 20 ve 
30 gün sonra $40 \mathrm{~g} \mathrm{ha}^{-1}$ ve $50 \mathrm{~g} \mathrm{ha}^{-1}$ ile imazethapyr'in $25 \mathrm{~g} \mathrm{ha}^{-1}$ ve $40 \mathrm{~g} \mathrm{ha}^{-1}$ olmak üzere farklı dozlarının karșılaștırıldığı çalıșma sonucunda, en yüksek tane veriminin ekimden 20 gün sonra quizalofop $40 \mathrm{~g} \mathrm{ha}^{-1}$ dıșındaki tüm quizalofop uygulamalarından elde edildiği bildirilmiștir. Tüm bu sonuçların yanı sıra nohutta, chlorimuron-ethyl'in ciddi fitotoksisitesinin olduğu ve yabancı otları kontrol etmede etkili olmadığı da belirtilmiștir.

Nohut alanlarında yabancı otların kimyasal ve kültürel mücadelesi amacıyla pendimethalin+ekimden 40 gün sonra elle yolma işlemi ile etkili yabancı ot kontrolü sağlandığı ve yüksek verim elde edildiği bildirilmiștir [77].

Kaushik ve ark. [78] çıkış sonrası imazethapyr $75 \mathrm{~g} \mathrm{ha}^{-1}$ ile ekimden 50 gün sonra elle yolma uygulaması ile metrekareye düşen en düşük yabancı ot yoğunluğu (2.91) olarak kaydedilmiştir. Bu uygulamayı çıkış öncesi pendimethalin $0.75 \mathrm{~g} \mathrm{ha}^{-1}+$ ekimden 25 gün sonra elle yolma kombinasyonu metrekarede 3.19 yabancı ot ile takip etmiştir. Metrekaredeki en yüksek yabancı ot yoğunluğunun ise çıkış öncesi alachlor $2 \mathrm{~kg} \mathrm{ha}^{-1}$ uygulamasında olduğu belirtilmiştir.

Pendimethalin $0.75 \mathrm{~kg}$ ha ${ }^{-1}$ ekimden 45 gün sonra bir kez elle yolma ile kombinasyonunda etkili yabancı ot kontrolünün elde edildiği belirtilmiştir [79].

Abbas ve ark. [80] metolachlor+pendimethalin $2230 \mathrm{ml}^{-1}$ hagulamasının yabancı otların kontrolünde umut verici sonuçlar gösterdiğini belirtmişlerdir. Kachhadiya ve ark. [81] ekimden 30-35 gün sonra oxyfluorfen $0,12 \mathrm{~kg} \mathrm{ha}^{-1}+$ elle yolma ile çlkış öncesi fluchloralin $0,675 \mathrm{~kg}^{-1}+$ çıkış sonrası imazethapyr $0,05 \mathrm{~kg}^{-1}$ hagulaması sonunda yabancı otların kuru ağırlığının önemli ölçüde daha düşük kaydedildiğini ortaya koymuşlardır. Çıkış öncesi pendimethalin $0,75-1,5 \mathrm{~kg} \mathrm{ha}^{-1} \mathrm{ve}$ çıkış sonrası quizalofop-pethyl 40-100 $\mathrm{g} \mathrm{ha}^{-1}$ uygulamalarının etkili olduğu vurgulanmıştır [82].

Dewangan ve ark. [33] çıkıș öncesi oxyfluorfen+metribuzin $125+350 \mathrm{~g}^{\text {ha'-1'in tank }}$ karışımlarının kullanılmasıyla, kontrole göre verimde (\% 73.10) kayda değer bir artış olduğunu ortaya koymușlardır. Ancak ekimden 20 gün sonra metribuzin $250 \mathrm{~g} \mathrm{ha}^{-1}$ ve 12 gün sonra oxyfluorfen $125 \mathrm{~g} \mathrm{ha}^{-1}$ uygulamalarında nohutta fitotoksik etkilerin görüldügü belirtilmiștir.

Sulu koşullarda yetiştirilen nohutta çıkış öncesi ve sonrası herbisit uygulamaları ile elle yolma ve çapalamanın yabancı otlar ve nohut verimine olan etkilerinin değerlendirildiği çalışmada on farklı uygulama ele alınmıştır. Elde edilen sonuçlara göre en yüksek nohut verimi ve net getiri ile en düşük yabancı ot kuru ağırlığı ve en yüksek etki seviyesi (\% 83) çıkış öncesi pendimethalin+ekimden sonraki 30-35 gün sonra elle yolma uygulaması ve çıkış öncesi pendimethalin+imazethapyr+ekimden 30-35 gün sonra yapılan çapalama ile elde edildiği belirtilmiștir [83].

Nohut ekim alanlarında sorun olan yabancı otların kimyasal mücadelesinde aclonifen etkili maddeli herbisitin tavsiye ve azaltılmıș dozlarının üç farklı nohut çeșidinde (AzkanHisar-Sarı 98) kullanılmasının nohutta bazı parametreler üzerine olan etkisinin değerlendirildiği çalıșmada; klorofil oranı (KLO), yaprak alan (YA), kök uzunluğu (KU), nodül ağırlığı (NA), nodül sayısı (NS), bitki boyu (BB) ve kök kuru ağırlı̆̆ı (KKA) parametrelerine etkileri incelenmiștir. Yapılan uygulamalar sonucunda Rhizobium ciceri ırkı ile așılamanın NS ve NA, çeșitler içerisinde ise NA ve YA, parametrelerine etkileri istatistiki olarak önemli bulunmuş ve herbisitin incelenen parametreler üzerinde nohut gelişimine olumsuz bir etkisinin olmadığı belirtilmiştir [84]. 
Nohut ekim alanlarında sorun olan Sinapis arvensis mücadelesinde aclonifen'in tavsiye dozu ve azaltılmıș dozlarının yalnız bașına ve katkı maddesi ilavesi ile birlikte Azkan nohut çeșidinde kullanılmasının nohut gelișimi ve $S$. arvensis kontrolündeki etkinliğinin saksı koșullarında değerlendirildiği çalıșma sonucunda; herbisit uygulaması yapılan bitki grupları, kontrol ile kıyaslandığında nohut kuru ağırlığında olumsuz etki görülmezken, söz konusu yabancı otun mücadelesinde etkili olduğu bildirilmiştir [85].

Linuron etkili maddeli herbisitin farklı dozlarının üç farklı nohut çeşidinde (Azkan-HisarSarı 98), nohudun bazı parametreleri üzerine etkisinin değerlendirildiği çalıșmada steril edilmiș topraklarda așılı (Rhizobium ciceri) ve așısız olmak üzere iki farklı koșulda herbisitin etkileri ele alınmıștır. Linuron tavsiye dozu esas alınarak farklı dozlarda çıkıs öncesi uygulanmıș ve klorofil oranı (KLO), yaprak alanı (YA), kök uzunluğu (KU), nodül ağırlığı (NA), nodül sayısı (NS), bitki boyu (BB), bitki çıkıș oranı (BÇO) ve kök kuru ağırlık (KKA) parametrelerine etkileri incelenmiştir. Elde edilen sonuçlara göre; bakteri aşılaması KKA, KU, NS, NA ve BB parametrelerinde, çeşitler açısından KKA, KU ve BB parametrelerinde istatistiki olarak önemli bulunurken diğer parametreler arasındaki fark önemsizdir. Herbisit dozları açışından ise KLO harici tüm parametrelerde istatistiki farkın önemli olduğu bildirilmiştir [86].

Baklagillerde özellikle nohut üretiminde yabancı otların mücadelesinde çlkış öncesi uygulanan pendimethalin birçok türün mücadelesinde kullanılan yaygın bir herbisit olduğu ifade edilirken, çıkıș sonrası geniș yapraklı yabancı otları etkili bir șekilde kontrol etmek için yeterli bir herbisit bulunmadığı vurgulanmıştır [87].

Dubey ve ark. [87] nohut ekiminden 35 gün sonra çıkış sonrası oxyfluorfen $200 \mathrm{~g} \mathrm{ha}^{-1} \mathrm{ve}$ clodinafop $60 \mathrm{~g}^{\text {ha-1}}{ }^{-1} \mathrm{un}$ kök nodüllerinin oluşumu üzerinde toksik etkisini gözlemlemiş, çıkış sonrası pendimethalin $1 \mathrm{~kg} \mathrm{ha}^{-1}$, clodinafop $60 \mathrm{~g} \mathrm{ha}^{-1}$ uygulamasının dar ve geniş yapraklı yabancı otları etkili bir şekilde kontrol ettiği belirtilmiştir. Nohutta yabancı ot kontrol etkinliği, tane ve saman verimi açısından en etkili uygulamanın çıkış öncesi

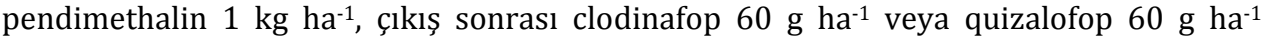
olduğu belirtilmiștir.

Rupareliya ve ark. [88] yapmış oldukları çalışma sonucunda çıkış öncesi oxyfluorfen 0.18 $\mathrm{kg} \mathrm{ha}^{-1}$ ve imazamox+imazethapyr $0.03 \mathrm{~kg} \mathrm{ha}^{-1}$ karışımı ile çıkış sonrası ekimden 40 gün sonra en düşük kuru yabancı ot ağırlığı (83 $\mathrm{kg} \mathrm{ha}^{-1}$ ) kaydedilmiștir. Ayrıca imazamox+imazethapyr $0.03 \mathrm{~kg} \mathrm{ha}^{-1}$ uygulaması ile en yüksek yabancı ot kontrolünün $(\%$ 92.23) sağlandığı bildirilmiştir.

Yadav ve ark. [89] ekimden 20 gün sonra çıkış öncesi pendimethalin $0.60 \mathrm{~kg} \mathrm{ha}^{-1}+$ çıkış sonrası imazethapyr $60 \mathrm{~g} \mathrm{ha}^{-1}$ uygulamasının önemli ölçüde daha yüksek verim kaydettiğini ve çıkış öncesi pendimethalin $0.60 \mathrm{~kg} \mathrm{ha}^{-1}+$ çıkış sonrası imazethapyr $40 \mathrm{~g}$ ha${ }^{1}$ ile elde edilen etkilerin benzer olduğu bulunmuştur.

Merga ve Alemu [37] s-metolachlor $1.0 \mathrm{~kg} \mathrm{ha}^{-1}$ uygulamasının nohut çıkışından 5 hafta sonra elle yolma ile kombinasyonunda en düşük toplam yabancı ot yoğunluğunun $(21.78$ $\mathrm{m}^{-2}$ ) elde edildiği belirtilmiştir.

Kışlık nohut ekim alanlarında yabancı ot mücadelesinde farklı meme tiplerinin uygulama zamanlarına göre etkinliğinin belirlenmesi amacıyla bazı herbisitler; (M1) standart yelpaze hüzmeli meme (çıkış öncesi), (M2) çıkış öncesi meme tipi (çıkış öncesi), (M3) çarpmalı meme tipi (çıkış öncesi), (M4) hava emişli meme (çıkış sonrası), (M5) ikiz hüzmeli hava emişli meme (çıkıș sonrası) iki farklı uygulama hacminde (200 ve $400 \mathrm{l}$ ha $\left.{ }^{1}\right)$ uygulanmıștır. Uygulamalar sonucunda yabancı ot kontrol etkinlikleri ve verim 
değerleri ele alındığında, $400 \mathrm{l} \mathrm{ha}^{-1}$ uygulama hacmi ve hava emișli meme (M4), \% 86.6 biyolojik etkinlik değerleri ve $476 \mathrm{~kg} \mathrm{da}^{-1}$ verim değeri ile en yüksek sonuçların elde edildiği uygulamalar olarak bildirilmiştir [90].

Kumar ve ark. [91] çalışmalarında çıkış öncesi pendimethalin $1 \mathrm{~kg} \mathrm{ha}^{-1}+$ çıkış sonrası quizalofop $60 \mathrm{~g} \mathrm{ha}^{-1}$ uygulamasının yabancı otların en düşük besin tüketimi sağladığını, çıkış öncesi pendimethalin $1 \mathrm{~kg} \mathrm{ha}^{-1}+$ çıkış sonrası imazethapyr $40 \mathrm{~g} \mathrm{ha}^{-1}$ uygulamasının ise bitkide en yüksek besin alımını ve en yüksek verimi sağladığını belirtmişlerdir.

\section{Sonuçlar ve Öneriler}

Tarımsal üretim toplumun beslenmesi için stratejik önemde olup, artan nüfusun gıda ihtiyacının karșılanması, gıda güvenliğinin ve doğal kaynakların korunması gibi faktörler tarımsal üretimin önemini daha da arttırmaktadır. Tarımsal üretimin sürdürülebilirliğinin sağlanmasında, ürün artıșında, uygun sulama ve gübreleme pratikleri, toprak ișleme teknikleri gibi faaliyetlerin yanında bitki koruma faaliyetlerinin de önemi büyük olup, bitkisel üretimi sınırlandıran, verim ve kalite kayıplarına sebep olan bitki koruma sorunlarından biri de yabancı otlardır. Yabancı otların mücadelesinde genel olarak kültürel önlemler, mekanik mücadele, fiziksel mücadele, biyolojik mücadele ve kimyasal mücadele ile entegre mücadele teknikleri kullanılmaktadır. Ancak uygulamanın kolay olması, daha yüksek etkinlik, hızlı sonuç ve maliyetinin düșük olması, seçiciliği, doğru zamanda ve düzgün bir ilaçlama tekniği ile etkinliğin sağlanması gibi avantajlarından dolayı herbisit uygulamaları ön plana çlkmaktadır. Ancak hatalı uygulamalar sonucunda karşılașılan çevre problemleri ve etkinlikte azalmalar gibi sorunları da beraberinde getiren herbisitlerin entegre mücadele kapsaminda değerlendirilmesiyle söz konusu olumsuz etkilerin en aza indirilmesi ve kültür bitkisinde doğrudan ve dolaylı verim artışına katkı sunması ümit verici bir duruma gelmiștir.

Nohut yetiștiriciliğinde sorun olan bazı yabancı ot türlerinin mücadelesinde özellikle üretici koșullarında zaman zaman sorunlar olduğu yönünde geri bildirimler alınmaktadır. Ülkemizde nohut üretim alanlarında yabancı ot türlerinin kimyasal mücadelesinde ruhsatlı olan herbisitlerin oldukça sınırlı sayıda olması, özellikle de mücadelesinin zor olduğu bilinen çok yıllık türlerin üretim alanlarında yaygın ve yoğun olarak yer alması söz konusu türlerden kaynaklı verim kayıplarının önlenmesinde etkili, ekonomik ve çevre dostu önlemlerin gerekliliğini ortaya koymaktadır. Dünyada nohut üretim alanlarında yabancı otların mücadelesindeki gelișmelere paralel olarak ülkemizde herbisitler ile yürütülen araștırma sonuçları değerlendirildiğinde; halihazırda ruhsatlı aktiflerin ele alındığı güncel çalıșma sayısı oldukça sınırlı durumdadır. Herbisitlerin tank karıșımlarının, kombinasyonlarının, koruyucu önlemler ile birlikte değerlendirilmesinin özellikle de farklı toprak ișleme yöntemlerinin ekim zamanı ile bölgelere göre ele alınmasının, mücadelesi zor olan türlerin hakim olduğu alanlarda etkili kontrolünün sağlanması açısından önemini ortaya koymaktadır. Sağlıklı bir çevre, sürdürülebilir tarım ve ekonomik kayıpların önlenmesinde herbisitlerin kullanım biçiminden kaynaklanan eksikliklerin ve hataların önüne geçilmesi, diğer mücadele teknikleri ile kombinasyonlarının ortaya konulması, özellikle de mücadelesi zor olan hakim türlerin ele alınmasının hem üretici hem de ülke ekonomisine katkı sunacağı düşünülmektedir. Sonuç olarak; erken gelişme döneminde rekabet yeteneği oldukça düşük olan nohutta yabancı otlarla mücadele programlarının koruyucu önlemler dikkate alınarak ekim ve çıkış öncesi herbisit uygulamalarının optimizasyonu ve entegre çalışmaları ile desteklenmesinin gerekliliği ayrıca yabancı ot türlerinin doğru teşhisi ve uygun zamanda doğru doz ile tekniğine uygun biçimde mücadelesinin gerekliliği ortaya çıkmaktadır. 


\section{Teşekkür}

$\mathrm{Bu}$ çalıșma, Burhan DİLEK'in Ușak Üniversitesi Lisansüstü Eğitim Enstitüsü, Tarım Bilimleri Anabilim Dalı'nda yüksek lisans tezi olarak yürütülen çalışmasının bir bölümünden hazırlanmıştır.

\section{Çıkar Çatışması Beyanı}

Makale yazarları aralarında herhangi bir çıkar çatışması olmadı̆̆ını beyan etmektedir.

\section{Kaynaklar}

1. Şehirali, S. Yemeklik tane baklagiller. AÜ Ziraat Fak. Yayınları, 1089, Ders Kitabı, Ankara; 1988. p. 314, 435.

2. Muelbauer FJ, Sarker A. Economic importance of chickpea production, value, and world trade. Journal Cogent Food \& Agriculture, 2017; 5(1), 5-12.

3. FAO, 2019. Birleşmiş Milletler Gıda ve Tarım Örgütü İstatistikleri. www.faostat.fao.org/ [Erişim tarihi: 14 Mayıs 2019]

4. Anonim, 2011 [Erişim tarihi:1 Ağustos 2021] https://arastirma.tarimorman.gov.tr/ttae/Sayfalar/Detay.aspx?SayfaId=63

5. Chisaka H. Weed damage to crops: yield loss due to weed competition. integrated control of weeds; ed. by J.D. Fryer ve S. Matsunaka. University of Tokyo Press.1-16, Tokyo, Japan; 1977.

6. Ratnam M, Rao AS, Reddy TY. Integrated weed management in chickpea (Cicer arietinum L.). Indian J. Weed Sci, 2011; 43: 70-72.

7. Chaudhary BM, Patel JJ, Delvadia DR. Effect of weed management practices and seed rates on weeds and yield of chickpea. Indian Journal of Weed Sciences, 2005; 37: 271-272.

8. Miller P, McKay K, Jenks B, Riesselman J, Bussan AJ. Growing chickpea in the northern great plains. Fargo, North Dakota: North Dakota State University, 2002. https://www.pulseusa.com/docs/chikpea.pdf.

9. Güncan A. Yabancı ot mücadelesi. Selçuk Üniversitesi Yayınevi, Konya, 2014.

10. Mennan H, Uygur FN. Samsun ili buğday ekim alanlarında görülen yabancı otların saptanması. OMÜ Ziraat Fakültesi Dergisi, 1994; 9 (2), 25-35.

11. Tepe I. Yabancı otlarla mücadele. Sidas Medya Ziraat Yayın No:031, İzmir, 2014.

12. Rao VS. Principles of Weed Science, Oxford and IBH puplishing Co.Pvt.Ltd New Delhi; 2000.

13. Barker B. Critical Weed free period of pulses. pulse advisor- Saskatchewan Pulse Growers, 2017; p. 1-3.

14. Basler F. Weeds and their control. In: Lentils. (Eds:C. Webb and G. Hawtin). Common wealth Agricultural Bureaux, Slough, UK, 1981.

15. Bhan VM, Kukula S. Weeds and their control in chickpea. In: Saxena MC, Singh KB editors. The Chickpea. Wallingford: C.A.B. International; 1987.

16. Solh MB, Pala M. Weed control in chickpea. International Chickpea and Pieonpea Newsletter, 1990; 9: 93-92. 
17. Mohammadi G, Javanshir A, Khooie FR, Mohammadi SA, Zehtab Salmasi S. Critical period of weed interference in chickpea. Weed Research, 2005; 45(1): 57-63.

18. Şanlı A, Kaya M, Kara B. Nohut (Cicer arietinum L.) 'ta yabancı ot mücadele zamanları ile herbisit uygulamalarının verim ve bazı verim unsurlarına etkileri. Anadolu Tarım Bilim. Dergisi, 2009; 24(1): 13-20.

19. Singh A, Vashist KK, Kang JS. Chemical weed control in irrigated desi gram (Cicer arietinum L.). Indian Journal of Weed Science, 2003; 35(1-2): 136-138.

20. Shahzad M, Farooq M, Hussain M. Weed spectrum in different wheat-based cropping systems under conservation and conventional tillage practices in Punjab, Pakistan. Soil Till Res, 2016; 163: 71-9.

21. Kraehmer H, Stübler H. Technical demands and political restrictions for weed control. Julius-Kühn-Archiv, 434, 2012.

22. Uludağ A. Weed infestation level changes in cereal in Diyarbakir, Turkey. 10th EWRS Symposium, Poznan, 1997. p. 22.

23. Özaslan C. Diyarbakır ili buğday ve pamuk ekim alanlarında sorun olan yabancı otlar ile üzerindeki fungal etmenlerin tespiti ve bio-etkinlik potansiyellerinin araștırılması. Doktora Tezi, Selçuk Üniversitesi, Fen Bilimleri Enstitüsü, Konya, TÜRKIYE, 2011.

24. Töre Ö. Tokat ili buğday ekim alanlarında sorun olan yabancı ot türleri ile bunların yaygınlık ve yoğunluklarının belirlenmesi. Yüksek Lisans Tezi, Gaziosmanpaşa Üniversitesi, Fen Bilimleri Enstitüsü, TOKAT, 2014.

25. Pala F, Mennan H. Diyarbakır buğday tarlalarında bulunan yabancı otların belirlenmesi. Bitki Koruma Bülteni, 2017; 57(4): 447- 461.

26. Önen H, Akdeniz M, Farooq S, Hussain M, Özaslan, C. Weed flora of citrus orchards and factors affecting its distribution in western mediterranean region of Turkey. Planta Daninha, 2018; 36.

27. Sırrı M. Buğday ekim alanlarında sorun oluşturan türleri: Siirt ili örneği. Türkiye Tarımsal Araștırmalar Dergisi, 2019; 6(2):142-152.

28. Kadığlu İ, Uluğ E, Üremiş İ. Akdeniz bölgesi yemeklik baklagillerinde (Nohut, Fasulye) görülen yabancı otlar ile yaygınlık ve yoğunluklarının belirlenmesi, Türkiye II. Herboloji Kongresi, 1997; 195.

29. Demir A, Tepe I. Diyarbakır ili nohut ekiliş alanlarında saptanan önemli yabancı ot türleri, yaygınlık ve yoğunlukları. Türkiye Herboloji Dergisi, 2001; 4 (1), 2129

30. İșler N. Tokat (Zile'de) nohut (Cicer arietinum L.) yetiştirilen alanlarda sorun olan yabancı otların Belirlenmesi ve yabancı ot alımının verim ve nodozite oluşumuna etkileri üzerine araştırmalar. Yüksek Lisans Tezi, Gaziosmanpaşa Üniversitesi, Tokat, TÜRKIYE, 2003.

31. Eroğlu N. Karaman'da nohutlarda sorun olușturan yabancı otlar ve kritik periyodun belirlenmesi. Yüksek Lisans Tezi, Selçuk Üniversitesi, Konya, TÜRKIYE, 2006.

32. Üstüner T. Determination of weed density, frequency and general coverage areas in chickpea fields in Kahramanmaras, Turkish Journal of Weed Science, 2006; 19(2), 38-48.

33. Dewangan M, Singh AP, Chowdhury T, Kumar D, Kumar B. Management of complex weed flora in chickpea. Indian Journal of Weed Science, 2016; 48(1): 79-82.

34. Gore AK, Chavan AS, Gokhale DN, Thombre KM. Evaluation of new herbicides on weed flora and productivity of Chickpea (Cicer arietinum L.). International Journal of Current Microbiology and Applied Sciences, 2018; 7(5): 3682-3687. 
35. Pooniya V, Rai B, Jat RK. Yield and yield attributes of chickpea (Cicer arietinum L.) as influenced by various row spacings and weed control. Indian Journal of Weed Science, 2009; 41(3-4): 222-223.

36. Yadav VL, Shukla UN, Mehriya ML. Weed Dynamics and Yield of Chickpea (Cicer arietinum L.) as Influenced by Pre and Post-Emergence Herbicides. International Journal of Current Microbiology and Applied Sciences, 2018; 7(7): 2523-2532.

37. Merga B, Alemu N. Integrated weed management in chickpea (Cicer arietinum L.). Cogent Food and Agriculture, 2019; 5: 1-18.

38. Bhalla CS, Maliq RK, Vewan RP, Bhan VM. Herbicidal weed control in chickpea (Cicer arietinum L.). World Weeds, 1998; 5(1-2): 121-124.

39. Hassan G, Khan MI, Khan I. Effect of herbicides doses on fresh and dry biomass of different biotypes of Asphodelus tenuifolius at various growth stages. Sarhad Journal of Agriculture, 2007; 24(1): 101-105.

40. Güncan A, Karaca M. Yabancı ot mücadelesi. Selçuk Üniversitesi Basım Evi, Konya, 2018.

41. Malik RK, Balyan RS, Bhan VM. Effect of herbicides and planting dates on weeds in chickpea. Indian Journal of Weed Science, 1988; 20(2): 75-81.

42. Blessdal JKA. The Biology of Weeds (Harper JL). Blackwell Science, Publ. Oxford, UK, 1960; 133-142.

43. Whish JPM, Sindel BM, Jessop RS, Felton WL. The effect of row spacing and weed density on yield loss of chickpea. Australian Journal of Agricultural Research, 2002; 53: 1335-1340.

44. Numan A, Ali N, Khan MI, Rehman MU and Qadir A. Yield and yield parameters of chickpea varieties under different weed population in Thal area of Khyber Pakhtunkhwa. International Journal of Green and Herbal Chemistry, 2017; 7(1): 119-129.

45. Hossain MM, Begum M. Soil weed seed bank: Importance and management for sustainable crop production-A review. Journal of the Bangladesh Agricultural University, 2015; 13 (2), 221-228.

46. Young FL, Matthews J, Al-Menoufl A, Sauerborn J, Pieterse AH, Kharrat M. Integrated weed management for food legumes and lupins. In: Knight, R. (Ed.), Linking Research and Marketing Opportunities for Pulses in the 21 th Century, Kluwer Academic Publishers, Netherland, 2000; pp. 481-490.

47. Sönmez S. Türkiye herbisit pazarı-Türkiye I. Herboloji Kongresi, 1991 3-5 Şubat, Adana, Türkiye, 1991. p. 17-22.

48. Güncan A. Yabancı Otlar ve Mücadele Prensipleri. Selçuk Üniversitesi, Ziraat Fakültesi, Konya, 2002.

49. Mengüç C. Herbisit toksisitesi ve yabancı otlara karşı alternatif mücadele stratejileri. Turk J Weed Sci, 2018; 21(1): 61-73.

50. Mitkov A, Yanev M, Neshev N, Tonev T. Possibilities for chemical control of the weeds at chickpea (Cicer arietinum L.). In: Proceedings of the 52nd Croatian and 12th International Symposium on Agriculture "Field Crop Production", 12-17 February, Dubrovnik, Croatia, 2017.

51. Sunil CM, Shekara BG, Ashoka P, Murthy KK, Madhukumar V. Effect of integrated weed management practices on nutrient uptake in aerobic rice. Research on Crops, 2011; 12 (3): 629-632.

52. Cioni F. Pre-emergence dose rate reduction in spring and autumnal sugar beet sowing. In: Proceedings of the 60th IIRB Congress. Cambridge, 1997. p. 431-437.

53. May JM, Hilton JG. Reduced rates of pre-emergence herbicides (1982-1984). In: 77th Report of the Norfolk agricultural station, 1985. p. 14-21.

54. Cioni F, Maines G. Weed control in sugarbeet. Sugar Tech, 2010; 12(3), 243-255

55. May JM, Wilson RG. Weed and weed control. In Sugar beet, London, 2006. 
56. Balyan RS, Malik RK, Vedwan RPS, Bhan VM. Chemical weed control in chickpea (Cicer arietinum L.). Tropical Pest Management, 1987; 33(1): 16-18.

57. Kahraman A. Samsun ekolojik șartlarında nohutta yabancı otlarla mücadele yönteminin tespiti ve verime etkisi üzerine bir araștırma. Yüksek Lisans Tezi, Ondokuz Mayıs Üniversitesi, Fen Bilimleri Enstitüsü, Samsun, TÜRKIYE, 1993.

58. Plew JN, Hill GD, Dastgheib F. Weed control in chickpeas (Cicer arietinum). Proceedings Agronomy Society of N.Z; 1994.

59. Sesharee A, Prasad PVN, Rao KL, Rao KHP. Integrated weed management in gram (Cicer arietinum). Indian Journal of Agronomy, 1996; 41(3): 496-497.

60. Hosseini NM. Comparison of several herbicides for control of chickpea weeds. Iranian Journal of Plant pathology, 1997; 33(3-4): 73.

61. Uzun A, Topuz M. Ege Bölgesinde nohut alanlarında yabancı ot mücadelesi üzerinde araştırmalar. Türkiye II. Herboloji Kongresi 1-4 Eylül, İzmir Ayvalık, Ege Üniv. Basımevi. 1998.

62. Bacchi M, D-Alessandro F, Gallo G, Venora G. Selectivity and efficacy of some preemergence herbicides in chickpea (Cicer arietinum L.). Comtes rendus 6 Eme Symposium mediterraneen EWRS, Montpeller, France, 13-15 Mai, 1998; 321322.

63. Skrobakova E. The effect of pre-emergence treatment with herbicides on yield of chickpea (Cicer arietinum L.). Rostlinna Vyroba, 1998; 44(4): 183-186.

64. Vaishya RD, Rai OP, Singh SS. Weed control in chickpea with pre-emergence herbicides in Eastern Uttar Pradesh. Indian Jour. Of Pulses Research, 1999; 12(2): 197-200.

65. Kantar F, Elkoca E, Zengin H. Chemical and agronomical weed control in chickpea (Cicer arietinum L. cv. Aziziye-94). Turkish Journel. of Agric. and Forestry, 1999; 23(6): 631-635.

66. Thakar S, Brar LS, Walia US. Comparative efficiency of herbicides for weed control in chickpea (Cicer arietinum L.). Crop Research, 2000; 19(1): 1-5.

67. Malik MR, Haqqani AM, Habib-ur-Rehman, Ozair CA and Malik BA. Economic efficacy of different pre and post-emergence herbicides to control weeds in chickpea (Cicer arietinum L.). Journal of Biological Sciences, 2001; 1(5): 372-377.

68. Demir A, Tepe I, Erman M. Nohutta (Cicer arietinum L.) farkl mücadele yöntemlerinin yabancı otlanmaya, verime, bazı verim unsurlarına ve nodülasyona etkisi. Yüzüncü Yıl Üniversitesi Ziraat Fakültesi, Tarım Bilimleri Dergisi, 2005; 15(1): 71-77.

69. Lyon DJ, Wilson RG. Chemical weed control in dryland and irrigated chickpea. Weed Technology, 2005; 19(4): 959-965.

70. Kayan N. Orta Anadolu koşullarında farklı toprak işleme yöntemleri, yabancı ot kontrolü ve fosforlu gübre dozlarının nohutta verim ve verim öğelerine etkileri. Doktora Tezi, Fen bilimleri Enstitüsü, Ankara Üniversitesi, Ankara, TÜRKIYE, 2005.

71. Singh S, Walia US, Singh B. Effective control of weeds in chickpea (Cicer arietinum). Indian Journal of Weed Science, 2008; 40(1-2): 51-55.

72. Tanrı̈ver M. Isparta koşullarında nohutta yabancı ot mücadelesi üzerinde araştırmalar Doktora Tezi, Fen Bilimleri Enstitüsü, Selçuk Üniversitesi, Konya, TÜRKIYE, 2008.

73. Johnson E, Blackshaw R, Sapsford K, Holm F. Fall vs spring applied sulfentrazone for weed management in Chickpea (Cicer arientum). 5th Meeting International Weed Science Congress, Haziran, 2018; Vancouver, 2008. p. 192.

74. Tepe I, Erman M, Yergin R, Bükün B. Kuru tarım koşullarında yetiştirilen nohutta yabancl ot mücadelesinde kritik periyodun belirlenmesi. Türkiye III. Bitki Koruma Kongresi Bildirileri, 15-18 Temmuz 2009; Van, Turkey, 2009. p.45. 
75. Korkmaz Y, Kayan N. Farklı ekim ve yabancı ot kontrol yöntemlerinin nohutta (Cicer arietinum) verim ve verim öğelerine etkileri, Akdeniz Üniversitesi Ziraat Fakültesi Dergisi, 2010; 23(2): 157-162.

76. Khope D, Kumar S, Pannu RK. Evaluation of post-emergence herbicides in chickpea (Cicer arietinum). Indian Journal of Weed Science, 2011; 43(1-2): 9293.

77. Bhutada PO, Bhale VM. Efficacy of herbicides and cultural manegement on weed control in Gram (Cicer arietinum). IOSR Jaurnal of Agriculture and Veterinary Science, 2013; 4(5): 01-02.

78. Kaushik SS, Rai AK, Sirothia P, Sharma AK, Shukla AK. Growth, yield and economics of rain-fed chickpea (Cicer arietinum L.) as influenced by integrated weed management. Indian Journal of Natural Products and Resources, 2014; 5(3): 282-285.

79. Chandrakar S, Sharma A, Thakur DK. Effect of weed management on weeds and yield of chickpea varieties (Cicer arietinum L.). Advance Research Journal of Crop Improvement, 2015; 6(1):1-4.

80. Abbas G, Ahmed A, Amer M, Abbas Z, Mudassir-ur-Rehman, Hussain A, Khan GA. Impact of pre-emergence herbicides for the control of weeds in Chickpea (Cicer arietinum L.) under hot arid climate. Journal of Bioresource Management, 2016; 3(2): 54-60.

81. Kachhadiya SP, Savaliya JJ, Bhalu VB, Pansuriya AG, Savaliya SG. Evaluation of new herbicides for weed management in Chickpea (Cicer arietinum L.). Legume Research, 2009; 32(4): 293-297.

82. Pedde KC. Chemical weed control in chickpea (Cicer arietinum L.). M.Sc. Thesis. Vasantrao Naik Marathwada Krishi Vidyapeeth, Parbhani, 2016. pp. 135.

83. Rathod PS, Patil DH, Dodamani BM. Evaluation of time and dose of imazethapyr in controlling weeds of chickpea (Cicer arietinum L.). Legume Research, 2017; 40(5): 906-910.

84. Ögüt Yavuz D, Topal N, Cerit $\mathrm{O}$, Çetin O. Aclonifen etkili maddeli herbisitin nohut (Cicer arietinum L.) gelişimine olan etkileri, Akademia Mühendislik ve Fen Bilimleri Dergisi, 2017. ICAE- IWCB 2017 Special Issue.

85. Ögüt Yavuz D, Köktaș D. Nohut ekim alanlarında sorun olan Sinapis arvensis L. (Yabani hardal) mücadelesinde Aclonifen etkinliği, Akademia Mühendislik ve Fen Bilimleri Dergisi, 2017. ICAE- IWCB 2017 Special Issue.

86. Topal N, Öğüt Yavuz D, Ateş MS. Așılı (Rhizobium ciceri) ve aşısız toprak koșullarında linuron etkili maddeli herbisitin farklı nohut çeșitlerine etkileri, Academia Journal of Engineering and Applied Sciences, ICAE-IWCB 2017 Special Issue.

87. Dubey SK, Kumar A, Singh D, Partap T, Chaurasiya A. Effect of different weed control measures on performance of chickpea under irrigated condition. International Journal of Current Microbiology and Applied Sciences, 2018; 7(5): 3103-3111.

88. Rupareliya VV, Chovatia PK, Vekariya SJ, Javiya PP. Evaluation of pre and post emergence herbicides in chickpea (Cicer arietinum L.). International Journal of Chemical Studies, 2018; 6(1): 1662-1665.

89. Yadav VL, Shukla UN, Raiger PR, Mandiwal M. Efficacy of pre and postemergence herbicides on weed control in chickpea (Cicer arietinum L.). Indian Journal of Agriculture Research, 2019; 53(1): 112-115.

90. Bolat A, Bayat A, Tetik Ö, Türkeri M. Nohut ekim alanlarında yabancı ot mücadelesinde farklı meme tiplerinin uygulama zamanlarına göre etkinliğinin belirlenmesi. Yüzüncü Yıl Üniversitesi, Tarım Bilimleri Dergisi, 2019; 29 (3): 397-405. 
91. Kumar N, Kumar S, Sharma S. Efficacy of different herbicides on yield and nutrient uptake of chickpea (Cicer arietinum L.). International Archive of Applied Sciences and Technology, 2020; 11(3): 91-97. 